\title{
The Investigation of Plasma Glucagon-like Peptide-1 Levels in Newly Diagnosed Type 1 Diabetic Children

\author{
B Uslu ${ }^{1}$, F Gurbuz 2 , F Temiz², B Yuksel², N Mungan², AK Topaloglu²
}

\begin{abstract}
Objective: To reveal the possible role of glucagon-like peptide-1 (GLP-1) in newly diagnosed Type 1 diabetic children.

Methods: Twenty-five newly diagnosed children and 22 healthy children were included in the study.

Results: In oral glucose tolerance tests, no correlation was observed between C-peptide and GLP-1 levels at 0 and 30 minutes, and plasma GLP-1 levels in both groups at 0 and 30 minutes were not statistically different.

Conclusion: Consequently, fasting and postprandial GLP-1 levels in newly diagnosed Type 1 diabetic children are not different from healthy children. Glucagon-like peptide-1 levels in newly diagnosed Type 1 diabetic children suggest that plasma GLP-1 levels do not have any role in the pathogenesis of Type 1 diabetes mellitus.
\end{abstract}

Keywords: Children, C-peptide, glucagon-like peptide-1, Type 1 diabetes mellitus

\section{Investigación de los Niveles Plasmáticos del Péptido-1 Similar al Glucagón en Niños Recientemente Diagnosticados con Diabetes Tipo 1}

\author{
B Uslu ${ }^{1}$, F Gurbuz ${ }^{2}$, F Temiz ${ }^{2}$, B Yuksel ${ }^{2}$, N Mungan ${ }^{2}$, AK Topaloglu ${ }^{2}$
}

\begin{abstract}
RESUMEN
Objetivo: Revelar el posible papel del péptido-1 similar al glucagón (GLP-1) en recientemente diagnosticados con diabetes tipo 1.

Métodos: Veinticinco niños recientemente diagnosticados con diabetes tipo 1 y 22 niños sanos, fueron incluidos en el estudio.

Resultados: En las pruebas orales de tolerancia a la glucosa, no se observó correlación entre el péptido $C y$ los niveles de GLP-1 en 0 y 30 minutos, y los niveles plasmáticos de GLP-1 en ambos grupos en 0 y 30 minutos no fueron estadísticamente diferentes.

Conclusión: En consecuencia, los niveles de GLP-1 en ayuno y postprandiales en niños diabéticos de tipo 1 recién diagnosticados, no son diferentes de los de los niños sanos. Los niveles de péptido-1 similar al glucagón en niños diabéticos de tipo 1 recién diagnosticados sugieren que los niveles de GLP-1 en plasma no tienen ningún papel en la patogénesis de la diabetes mellitus tipo 1.
\end{abstract}

Palabras claves: Niños, péptido C, péptido-1 similar al glucagón, diabetes mellitus tipo 1

West Indian Med J 2016; 65 (1): 141

From: ${ }^{1}$ Department of Pediatrics and ${ }^{2}$ Department of Pediatric Endocrinology, Cukurova University, Adana, Turkey.

Correspondence: Dr F Gürbüz, Cukurova University, Medical Faculty, Department of Pediatric Endocrinology, 01330 Adana, Turkey. Fax: +90 322 3387717; e-mail: fggurbuz@yahoo.com

\section{INTRODUCTION}

Type 1 diabetes mellitus develops as a consequence of progressive pancreatic beta cell destruction and associated loss of function caused by uncontrolled autoimmune activities (1-3). Gastrointestinal peptides, GIP (glucose-dependent insulinotropic polypeptide) and GLP-1 (glucagon-like peptide-1) are incretin hormones released from the intestines in response to food intake and they, in turn, increase insulin secretion $(4,5)$. 
Glucagon-like peptide-1 is synthesized in enteroendocrine cells in the distal regions of the small intestine and colon $(4,6)$. The active incretin hormone GLP-1 (7-36) amide is a 30 amino acid peptide that exerts glucoregulatory and insulinotropic actions by functioning as an agonist for the GLP-1 receptor [GLP-1R] $(7,8)$. The main activator of GIP and GLP-1 is food intake. The purpose of this study is to examine plasma GLP-1 levels in children with Type 1 diabetes and to investigate and clarify whether this parameter plays a role in aetiopathogenesis of the disease.

\section{SUBJECTS AND METHODS}

This study was approved by the Ethics Committee of the Cukurova University, Faculty of Medicine, Adana, Turkey. Written informed consent was obtained from parents of each patient. The study included 25 prepubertal patients ( 16 boys and 9 girls) recently diagnosed with Type 1 diabetes, aged $108.48 \pm 29.66$ months. The control group consisted of 22 healthy children (11 boys and 11 girls), aged $92.4 \pm 26.63$ months.

In the patient group, plasma and serum samples were collected during the clinical onset of diabetes, at the time of diagnosis when all patients were hospitalized due to diabetic ketoacidosis, and were treated and educated on diabetes and administration of insulin; samples from the control group were collected during routine outpatient clinics.

In the patient group, three-hour postprandial oral glucose tolerance test (OGTT) was performed after 24 hours following improvement of ketoacidosis. In the healthy group, eight-hour pre-prandial OGTT was performed in the morning. Glucose solution containing $1.75 \mathrm{~g} / \mathrm{kg}$ glucose (maximum $75 \mathrm{~g}$ ) was administered.

Gender, age (months), weight $(\mathrm{kg})$ and height $(\mathrm{cm})$ values of all cases were recorded. Body mass index (BMI) values were calculated by the formula of weight $(\mathrm{kg}) \div$ height $(\mathrm{m})^{2}$. Plasma GLP-1 level was measured by Linco Research ${ }^{\circledR}$ glucagon-like peptide-1 (active) RIA kit (Cat\#GLP1A-35HK) using radioimmunoassay method. This kit is used to measure quantitative values of biologically active GLP-1 [GLP-1 (736) amide or GLP-1 (7-37) amide] in plasma. Analysis process was performed as per recommendations of kit manufacturer.

SPSS (version 16.0) package programme was used in statistical analysis. Parametric and nonparametric methods were used in analysis where significance level was accepted as $0.05 . T$-test and Wilcoxon test were performed according to normal distribution criteria of dependent or independent variables in the groups. In addition, correlation between the variables was analysed by Pearson correlation coefficient.

\section{RESULTS}

Distribution of age, height, weight, BMI and glycated haemoglobin $\left(\mathrm{HbA}_{1 \mathrm{c}}\right)$ levels are presented in Table 1. Furthermore, the comparison of glucose, C-peptide and GLP-1 levels, and the distribution of C-peptide and GLP-1 levels in groups are presented in Tables 2 and 3. No statistical difference was found between C-peptide levels at 0 and 30 minutes in the patient group $[p=0.501]$. In the control group, statistically significant difference was found for C-peptide levels at 0 and 30 minutes $[p<0.001]$ (Table 4).

No statistically significant difference was found in GLP1 values at 0 and 30 minutes in the patient group [ $p=0.319$ ] (Table 4). In the control group, no statistically significant difference was found between GLP-1 levels at 0 and 30 minutes $[p=0.211]$ (Table 4).

No correlation was observed between C-peptide and GLP-1 levels at 0 minutes in the patient group $(p=0.551)$. In the control group, C-peptide and GLP-1 values at 0 minutes were found not to correlate $(p=0.882)$. Similarly, no correlation was found between C-peptide and GLP-1 levels at 30 minutes in the Type 1 diabetes group ( $p=0.958)$. C-peptide and GLP-1 levels at 30 minutes in the control group were not correlated $[p=0.758]$ (Table 5).

Table 1: Distribution of age, height, weight, $\mathrm{BMI}$ and $\mathrm{HbA}_{1 \mathrm{c}}$ levels

\begin{tabular}{|c|c|c|c|c|c|c|}
\hline Group & & $\begin{array}{c}\text { Age } \\
\text { (months) }\end{array}$ & $\begin{array}{l}\text { Height } \\
(\mathrm{cm})\end{array}$ & $\begin{array}{l}\text { Weight } \\
\text { (kg) }\end{array}$ & $\begin{array}{c}\text { BMI } \\
\left(\mathrm{kg} / \mathrm{m}^{2}\right)\end{array}$ & $\begin{array}{c}\mathrm{HbA}_{1 \mathrm{c}} \% \\
(\mathrm{mmol} / \mathrm{mol})\end{array}$ \\
\hline \multirow{5}{*}{$\begin{array}{l}\text { Diabetic } \\
\text { group } \\
(\mathrm{n}=\mathbf{2 5})\end{array}$} & Mean & 108.48 & 131.56 & 29.180 & 16.2676 & $12.2(110)$ \\
\hline & Median & 117.00 & 135.00 & 30.00 & 15.9000 & 11.7 (104) \\
\hline & SD & 29.664 & 15.210 & 10.77211 & 3.04103 & $2.34(25.6)$ \\
\hline & Minimum & 51 & 98 & 15.00 & 12.00 & $8.6(70)$ \\
\hline & Maximum & 169 & 156 & 61.50 & 25.00 & $17.6(169)$ \\
\hline \multirow{5}{*}{$\begin{array}{l}\text { Control } \\
\text { group } \\
(n=22)\end{array}$} & Mean & 92.41 & 121.86 & 24.2364 & 15.9564 & $4.93(30)$ \\
\hline & Median & 98.50 & 125.00 & 24.50 & 15.6900 & $4.96(31)$ \\
\hline & $\mathrm{SD}$ & 26.631 & 13.566 & 7.21807 & 1.98756 & $0.20(2.2)$ \\
\hline & Minimum & 48 & 96 & 15.00 & 12.86 & $4.5(26)$ \\
\hline & Maximum & 132 & 140 & 42.00 & 21.40 & $5.26(34)$ \\
\hline
\end{tabular}

BMI: body mass index; $\mathrm{HbA}_{1 \mathrm{c}}$ : glycated haemoglobin; n: number of cases; $\mathrm{SD}$ : standard deviation 
Table 2: Comparison of glucose, C-peptide and GLP-1 levels of groups

\begin{tabular}{|c|c|c|c|c|c|c|c|}
\hline \multirow{2}{*}{ Groups } & & \multicolumn{2}{|c|}{ Glucose (mg/dL) } & \multicolumn{2}{|c|}{ C-peptide (pg/mL) } & \multicolumn{2}{|c|}{$\begin{array}{l}\text { GLP-1 } \\
(\mathrm{pg} / \mathrm{mL})\end{array}$} \\
\hline & & $\begin{array}{c}0 \\
\min \end{array}$ & $\begin{array}{l}30^{\text {th }} \\
\min \end{array}$ & $\begin{array}{c}0 \\
\min \end{array}$ & $\begin{array}{l}30^{\text {th }} \\
\min \end{array}$ & $\begin{array}{c}0 \\
\min \end{array}$ & $\begin{array}{l}30^{\text {th }} \\
\min \end{array}$ \\
\hline \multirow{6}{*}{$\begin{array}{l}\text { Type } 1 \\
\text { diabetic } \\
\text { children }\end{array}$} & $\mathrm{n}$ & 25 & 25 & 25 & 25 & 24 & 25 \\
\hline & Mean & 160.52 & 290.64 & 0.49276 & 0.51296 & 129.54 & 126.79 \\
\hline & Median & 138.00 & 298.00 & 0.34700 & 0.35600 & 124.50 & 125.68 \\
\hline & $\mathrm{SD}$ & 94.425 & 118.432 & 0.461956 & 0.508572 & 16.973 & 12.165 \\
\hline & Minimum & 44 & 86 & 0.027 & 0.032 & 104 & 106 \\
\hline & Maximum & 407 & 526 & 1.960 & 2.430 & 162 & 164 \\
\hline \multirow{6}{*}{$\begin{array}{l}\text { Healthy } \\
\text { children }\end{array}$} & $\mathrm{n}$ & 22 & 22 & 22 & 22 & 22 & 20 \\
\hline & Mean & 77.00 & 118.00 & 1.57955 & 3.65909 & 130.10 & 133.50 \\
\hline & Median & 78.00 & 116.00 & 1.23500 & 3.61000 & 126.50 & 128.00 \\
\hline & $\mathrm{SD}$ & 12.832 & 29.168 & 1.143200 & 1.408271 & 14.618 & 16.401 \\
\hline & Minimum & 33 & 61 & 0.306 & 1.120 & 102 & 109 \\
\hline & Maximum & 97 & 170 & 5.0 & 6.520 & 167 & 170 \\
\hline
\end{tabular}

GLRI: glucagon-like peptide-1; min: minute, n: number of cases, SD: standard deviation

Table 3: Distribution of C-peptide and GLP-1 levels in groups

\begin{tabular}{|c|c|c|c|c|c|}
\hline Groups & & & Mean & $\mathbf{n}$ & SD \\
\hline \multirow[t]{4}{*}{ Type 1 diabetic children } & C-peptide & $0 \mathrm{~min}$ & 0.49276 & 25 & 0.461956 \\
\hline & $(\mathrm{pg} / \mathrm{mL})$ & $30^{\text {th }} \min$ & 0.51296 & 25 & 0.508572 \\
\hline & GLP-1 & $0 \mathrm{~min}$ & 129.54 & 24 & 16.973 \\
\hline & $(\mathrm{pg} / \mathrm{mL})$ & $30^{\text {th }} \mathrm{min}$ & 126.79 & 24 & 12.165 \\
\hline \multirow[t]{4}{*}{ Healthy children } & C-peptide & $0 \mathrm{~min}$ & 1.57955 & 22 & 1.143200 \\
\hline & $(\mathrm{pg} / \mathrm{mL})$ & $30^{\text {th }} \min$ & 3.65909 & 22 & 1.408271 \\
\hline & GLP-1 & $0 \mathrm{~min}$ & 130.10 & 20 & 14.618 \\
\hline & $(\mathrm{pg} / \mathrm{mL})$ & $30^{\text {th }} \mathrm{min}$ & 133.50 & 20 & 16.401 \\
\hline
\end{tabular}

GLP-1: glucagon-like peptide-1; min: minute; n: number of cases; SD: standard deviation

Table 4: Distributions of differences between GLP-1 levels of 0 and 30 minutes and C-peptide levels of 0 and 30 minutes

\begin{tabular}{|c|c|c|c|c|c|c|}
\hline & & Mean & SD & Minimum & Maximum & $p$ \\
\hline \multirow{2}{*}{$\begin{array}{l}\text { Type } 1 \\
\text { diabetic } \\
\text { children }\end{array}$} & $\begin{array}{l}\Delta \mathrm{C} \text {-peptide } \\
(\mathrm{pg} / \mathrm{mL})\end{array}$ & 0.0202 & 0.479033 & -2.17935 & 0.177535 & 0.501 \\
\hline & $\begin{array}{l}\Delta \mathrm{GLP}-1 \\
(\mathrm{pg} / \mathrm{mL})\end{array}$ & -2.750 & 18.385 & -5.013 & 10.513 & 0.319 \\
\hline \multirow[t]{2}{*}{$\begin{array}{l}\text { Healthy } \\
\text { children }\end{array}$} & $\begin{array}{l}\Delta \mathrm{C} \text {-peptide } \\
(\mathrm{pg} / \mathrm{mL})\end{array}$ & 2.079545 & 1.327615 & -2.668177 & -1.490914 & $<0.001$ \\
\hline & $\begin{array}{l}\Delta \mathrm{GLP}-1 \\
(\mathrm{pg} / \mathrm{mL})\end{array}$ & 3.400 & 24.705 & -14.962 & 8.162 & 0.211 \\
\hline
\end{tabular}

GLP-1: glucagon-like peptide-1; min: minute; $\Delta$ : difference between 0 and $30^{\text {th }}$ minute; SD: standard deviation 
Table 5: Correlation of GLP-1 and C-peptide levels between groups

\begin{tabular}{|c|c|c|c|c|c|c|c|}
\hline \multirow{2}{*}{\multicolumn{4}{|c|}{ Groups }} & \multicolumn{2}{|c|}{ C-peptide } & \multicolumn{2}{|l|}{ GLP-1 } \\
\hline & & & & & & & \\
\hline \multirow{24}{*}{ 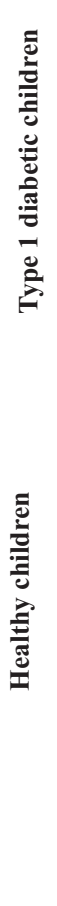 } & \multirow{6}{*}{ C-peptide } & \multirow[t]{3}{*}{$0 \mathrm{~min}$} & Pearson correlation & 1 & $0.516^{* *}$ & 0.128 & 0.049 \\
\hline & & & $p$ & & 0.008 & 0.551 & 0.818 \\
\hline & & & $\mathrm{n}$ & 25 & 25 & 24 & 25 \\
\hline & & \multirow[t]{3}{*}{$30^{\text {th }}$ min } & Pearson correlation & $0.516^{* *}$ & 1 & 0.093 & -0.011 \\
\hline & & & $p$ & 0.008 & & 0.664 & 0.958 \\
\hline & & & $\mathrm{n}$ & 25 & 25 & 24 & 25 \\
\hline & \multirow{6}{*}{ GLP-1 } & \multirow[t]{3}{*}{0 min } & Pearson correlation & -0.128 & 0.093 & 1 & 0.237 \\
\hline & & & $p$ & 0.551 & 0.664 & & 0.264 \\
\hline & & & $\mathrm{n}$ & 24 & 24 & 24 & 24 \\
\hline & & \multirow[t]{3}{*}{$30^{\text {th }} \min$} & Pearson correlation & 0.049 & -0.011 & 0.237 & 1 \\
\hline & & & $p$ & 0.818 & 0.958 & 0.264 & \\
\hline & & & $\mathrm{n}$ & 25 & 25 & 24 & 25 \\
\hline & \multirow[t]{6}{*}{ C-peptide } & \multirow[t]{3}{*}{0 min } & Pearson correlation & 1 & $0.474 *$ & -0.034 & 0.057 \\
\hline & & & $p$ & & 0.026 & 0.882 & 0.807 \\
\hline & & & $\mathrm{n}$ & 22 & 22 & 22 & 20 \\
\hline & & \multirow[t]{3}{*}{$30 \mathrm{~min}$} & Pearson correlation & 0.474 & 1 & -0.074 & -0.072 \\
\hline & & & $p$ & 0.026 & & 0.743 & 0.758 \\
\hline & & & $\mathrm{n}$ & 22 & 22 & 22 & 20 \\
\hline & \multirow[t]{6}{*}{ GLP-1 } & \multirow[t]{3}{*}{0 min } & Pearson correlation & -0.034 & -0.074 & 1 & $-0.445^{*}$ \\
\hline & & & $p$ & 0.882 & 0.743 & & 0.043 \\
\hline & & & $\mathrm{n}$ & 22 & 22 & 22 & 20 \\
\hline & & \multirow[t]{3}{*}{$30 \mathrm{~min}$} & Pearson correlation & 0.057 & -0.072 & $-0.445 *$ & 1 \\
\hline & & & $p$ & 0.807 & 0.758 & 0.043 & \\
\hline & & & $\mathrm{n}$ & 20 & 20 & 20 & 20 \\
\hline
\end{tabular}

GLP-1: glucagon-like peptide-1; min: minute; n: number of cases

*Meaningful critical value for correlation: 0.05

**Meaningful critical value for correlation: 0.01

No correlation was found between mean ages of the groups and GLP-1 levels at 0 and 30 minutes ( $p=0.999$ and $p$ $=0.650$, respectively). No correlation was determined between mean weights of the groups and GLP- 1 levels at 0 and 30 minutes ( $p=0.123$ and $p=0.549$, respectively). Mean heights of the groups and GLP-1 levels at 0 and 30 minutes were not correlated ( $p=0.793$ and $p=0.449$, respectively). No correlation was observed between mean BMI values of the groups and GLP-1 levels at 0 and 30 minutes $(p=0.273$ and $p=0.937$, res-pectively). No correlation was found between mean $\mathrm{HbA}_{1 \mathrm{c}}$ percentages in the groups and GLP- 1 levels at 0 and 30 minutes $(p=0.370$ and $p=0.130$, respectively). Blood glucose values at 0 and 30 minutes were found to not correlate with GLP-1 levels at 0 and 30 minutes $(p=0.627)$. Since no correlation was detected with any of the variables, regression analysis was not performed.

\section{DISCUSSION}

Up to this date, most of the studies conducted on GLP-1 were performed on adult Type 2 diabetic patients. Studies regarding GLP-1 in Type 1 diabetes cases are scarce (9). Since Type 1 diabetes constitutes more than $90 \%$ of all diabetes cases in childhood, we performed the current study on children with Type 1 diabetes.
Greenbaum et al (10) compared individuals with disturbed glucose tolerance and Type 1 diabetes patients with a control group. In both, evaluations were performed following intravenous glucose tolerance test (IVGTT) and OGTT. Similar to the current study, fasting and postprandial plasma GLP1 concentrations were determined to be similar. Evaluation of incretin activity revealed a more significant increase in insulin levels in the control group; they concluded that discrepant effects of GLP-1 on insulin levels observed in control and diabetic groups, despite similar GIP and GLP-1 levels, are related to inadequate GLP-1 activity in diabetic patients.

Lugari et al (11) evaluated plasma glucose, insulin, Cpeptide and GLP-1 levels at 0,30 and 60 minutes following a 230-calorie meal in 16 Type 1 diabetic patients, 14 Type 2 diabetic patients and 10 healthy individuals as the control group. Among Type 1 diabetic patients, basal GLP-1 level was measured as $106.5 \pm 1.5 \mathrm{pg} / \mathrm{mL}$ but similar to results in the current trial, no statistical difference was found between postprandial and basal GLP-1 levels $(p>0.05)$. They concluded that disturbance of glucose sensitivity to intestinal L cells and associated decrease in GLP-1 release is one of the underlying causes of chronic hyperglycaemia and insulin deficiency (11).

In a study conducted by Meneilly et al (12) on Type 1 diabetic adult patients, fasting and postprandial GLP-1 and C- 
peptide responses following a mixed meal were evaluated. Fasting GLP-1 level was measured as $102.24 \pm 9.89 \mathrm{pg} / \mathrm{mL}$ while postprandial values after infusion was measured as $494.72 \pm 56.06 \mathrm{pg} / \mathrm{mL}$. No difference was found in C-peptide responses. As a conclusion, the authors suggested that nil response in C-peptide values, despite an increase in GLP-1 levels, is due to a deficiency of beta cell response to GLP-1 (12). Limb et al (13) implemented an analysis on two groups of healthy individuals with an age range of 15-28 years with the aim of evaluating the effect of oral and intravenous glucose on GLP-1 release. While intravenous glucose loading was performed in one group until the blood glucose levels reached 125 $\mathrm{mg} / \mathrm{dL}$, oral glucose of $30 \mathrm{~g}$ was administered in the other group. No difference was found between the two administration paths of glucose in terms of effect on GLP-1 and this was associated with administration of oral glucose instead of the mixed meal test (13).

Similarly, in the current trial, we could have obtained different GLP-1 levels if a mixed meal was used instead of oral glucose. Glucagon-like peptide-1 concentrations in circulation begin to increase after 15 minutes following food intake. Peak concentration of GLP-1 was achieved in 30-45 minutes. It decreased to basal levels after two to three hours (14). Similar to results of the current trial, sampling for GLP-1 response to oral glucose was performed at 30 minutes. In contrast to our expectations of increased plasma GLP-1 levels as a response to glucose intake in Type 1 diabetes, we found decreased plasma GLP-1 levels at 30 minutes as compared to fasting plasma GLP-1 values, though the decrease was minimal. A small increase was detected in plasma GLP-1 levels in the control group. However, no statistically significant difference was found for GLP-1 levels at 0 minutes (fasting) and at 30 minutes following oral glucose tolerance test in both groups. In addition, no difference was observed between the two groups in terms of change in GLP-1 values. A limited correlation was determined between GLP-1 levels at 0 and 30 minutes in the control group ( $\mathrm{rp}=0.043)$. Assessment of correlation with $\mathrm{C}$ peptide revealed no correlation between GLP-1 and C-peptide levels. In evaluation of serum C-peptide levels, an increase was observed in C-peptide release as a response to glucose in the control group, as expected; however, no statistically significant difference was found in release of C-peptide in the Type 1 diabetes group due to insufficient or no synthesis of insulin.

Results of several studies indicated lower GLP-1 levels in diabetic patients; however, plasma levels similar to healthy individuals were determined in other trials. Besides, since most of the studies were conducted on adult Type 2 diabetic patients, further trials are required to reach implicit conclusions regarding the role and significance of changes in plasma GLP-1 levels on aetiology of Type 1 diabetic patients; nevertheless, we believe that our study is important in terms of providing an insight on this topic.

Since GLP-1 is a hormone released from the intestines as a response to food intake, mechanical factors like amount and content of food and physiological factors like structure and integrity of intestinal lumen are indicated as factors with an impact on plasma GLP-1 levels. In light of these factors, our results indicating higher fasting plasma GLP-1 levels as compared to values indicated in other trials may be associated with greater ratios of intestinal length to body length in children, as opposed to adult patients. Very high plasma GLP-1 levels in patients diagnosed with intestinal hyperplasia associated with neuroendocrine tumours support this explanation. Glucagonlike peptide-1 levels are especially important in studies evaluating intestinal pathologies; however, the therapeutic role of supraphysiological GLP-1 doses is more relevant in diabetes, rather than plasma levels.

In conclusion, no difference was found in GLP-1 levels, both in healthy and in diabetic children. Therefore, we did not observe a significant effect of plasma GLP-1 levels released as a response to oral glucose intake on pancreatic insulin synthesis immediately following the diagnosis. Acute insulin response to GLP-1 is lacking in this phase of Type 1 diabetic patients (15). As a subsequent study to this one, a study assessing corresponding values in the first month and during the honeymoon stage may provide relevant stimulating data.

\section{AUTHORS' NOTE}

This research received no specific grant from any funding agency in the public, commercial, or not-for-profit sectors. All authors declare that they have no conflicts of interest.

\section{REFERENCES}

1. Fiallo-Scharer R, Eisenbarth GS. Pathophysiology of insulin-dependent diabetes. In: Pescovitz OH, Eugster EA. Pediatric endocrinology. $11^{\text {th }}$ ed. Philadelphia (USA): Lippincott Williams and Wilkins; 2004: 403-26.

2. Keskin M, Aygün A, Pehlivan S, Keskin O, Kor Y, Balat A et al. Trends in the frequency of HLA DR-DQ haplotypes among children and adolescents with type 1 diabetes mellitus in the southeast region of Turkey. J Clin Res Pediatr Endocrinol 2012; 4: 189-92.

3. Ergür AT, Oçal G, Berberoğlu M, Adiyaman P, Sıklar Z, Aycan Z et al. Celiac disease and autoimmune thyroid disease in children with type 1 diabetes mellitus: clinical and HLA-genotyping results. J Clin Res Pediatr Endocrinol 2010; 2: 151-4.

4. Drucker DJ. The biology of incretin hormones. Cell Metab 2006; 3: 153 65.

5. Perley MJ, Kipnis DM. Plasma insulin responses to oral and intravenous glucose: studies in normal and diabetic sujbjects. J Clin Invest 1967; 46: 1954-62.

6. List JF, Habener JF. Glucagon-like peptide 1 agonists and the development and growth of pancreatic beta-cells. Am J Physiol Endocrinol Metab 2004; 286: 875-81.

7, Mundil D, Cameron-Vendrig A, Husain M. GLP-1 receptor agonists: a clinical perspective on cardiovascular effects. Diab Vasc Dis Res 2012; 2: 95-108.

8. Gaspari T, Liu H, Welungoda I, Hu Y, Widdop RE, Knudsen LB et al. A GLP-1 receptor agonist liraglutide inhibits endothelial cell dysfunction and vascular adhesion molecule expression in an ApoE-/- mouse model. Diab Vasc Dis Res 2011; 8: 117-24.

9. Akıncı A, Aydın Ö, Özerol Hİ. Glucagon-like peptide-1 and -2 levels in children with diabetic ketoacidosis. J Clin Res Pediatr Endocrinol 2009; 1: $144-50$.

10. Greenbaum CJ, Prigeon RL, D'Alessio DA. Impaired beta-cell function, incretin effect, and glucagon suppression in patients with type 1 diabetes who have normal fasting glucose. Diabetes 2002; 51: 951-7. 
11. Lugari R, Dell'Anna C, Ugolotti D, Dei Cas A, Barlllı AL, Zandomeneghi $\mathrm{R}$ et al. Effect of nutrient ingestion on glucagon-like peptide 1 (7-36 amide) secretion in human type 1 and type 2 diabetes. Horm Metab Res 2000; 32: 424-8

12. Meneilly GS, McIntosh CH, Pederson RA, Habener JF, Gingerıch R, Egan JM et al. Effect of glucagon-like peptide 1 (7-36 amide) on insulinmediated glucose uptake in patients with type 1 diabetes. Diabetes Care 2003; 26: 837-42.

13. Limb C, Tamborlane WV, Sherwin RS, Pederson R, Caprio S. Acute incretin response to oral glucose is associated with stimulation of gastric inhibitory polypeptide, not glucagon-like peptide in young subjects Pediatr Res 1997; 41: 364-7.

14. Ranganath LR. Incretins: pathophysiological and therapeutic implications of glucose-dependent insulinotropic polypeptide and glucagon-like peptide-1. J Clin Pathol 2008; 61: 401-9.

15. McCulloch DK, Koerker DJ, Kahn SE, Bonner-Weir S, Palmer JP. Correlations of in vivo beta-cell function tests with beta-cell mass and pancreatic insulin content in streptozocin-administered baboons. Diabetes 1991; 40: 673-9. 